\title{
DAYASAING KOMODITAS HORTIKULTURA NEGARA BERKEMBANG DAN NEGARA MAJU DI PASAR INTERNASIONAL
}

\author{
Eko Purwo Santosa ${ }^{1}$, Muhammad Firdaus ${ }^{2}$,Tanti Novianti ${ }^{2}$ \\ ${ }^{1}$ Mahasiswa Program Pascasarjana Magister Ilmu Ekonomi, IPB \\ ${ }^{2}$ Staf Pengajar FEM IPB
}

\begin{abstract}
Horticulture is one of the agricultural sub-sector consisting of vegetables, fruits, biofarmaka mplants (medicinal plants) and floriculture (ornamentals) became one of the commodities subject of international trade, which the demand is increasing in line with increasing household income and growth population. During the period 2005-2014, the average growth value of horticultural exports of developing countries amounted to 69,81 percent higher than the average growth of exports in developed countries as big as 40,78 percent. The global trading of horticulture is faced with price volatility and trade barriers problems. In addition, the increasing demand of these commodities also in line with the increase in household incomes and population growth. Therefore, this study aimed to analyze the competitiveness of horticulture commodities in the international market and the factors that influence trade flow. The results of Export Product Dynamic (EPD) show that there are two horticultural export commodity that has dynamic market position in world market, there are bananas (HS.080300) and pineapples (HS.080430). Generally, the panel data analysis results show that prices, trade barriers, population, real GDP per capita, economic distances, and real exchange rates significantly affect export volumes.
\end{abstract}

Keywords: Competitiveness, Exports, Horticulture, Gravity model

\section{PENDAHULUAN}

Perdagangan pertanian global telah meningkat tajam selama tiga dekade terakhir, dan telah berubah dalam struktur dengan pentingnya peningkatan produk bernilai tinggi seperti produk hortikultura, susu dan produk daging. Komoditas hortikultura yang merupakan bagian produk pertanian telah memperoleh banyak perhatian di perdagangan internasional. Perkembangan liberalisasi perdagangan hortikultura dapat dikaitkan dengan keberhasilan Putaran Uruguay dan perundingan Perdagangan Multilateral selanjutnya. Sistem perdagangan pertanian dan pangan global sedang mengalami proses perubahan cepat, dengan implikasi penting bagi pembangunan ekonomi (Mergenthaler et al, 2009).

Hasil penelitian yang dilakukan oleh Haryadi (2008) menggunakan model GTAP (Global Trade Analysis Project), menunjukkan bahwa negara maju masih mendominasi perdagangan dunia baik untuk sektor industri maupun sektor pertanian sehingga pandangan bahwa negara maju mengekspor produk industri dan negara berkembang mengekspor produk pertanian ternyata tidak terbukti. Negara berkembang masih memiliki ketergantungan yang sangat kuat terhadap negara maju, termasuk bagi impor komoditi pertanian.

Selain itu, penghapusan hambatan perdagangan pertanian berdampak pada: (1) penurunan produksi, ekspor, dan 
impor pada sebagian besar sektor-sektor yang selama ini diberikan subsidi baik berupa dukungan domestik, maupun subsidi ekspor di negara maju, (2) peningkatan impor negara berkembang secara umum, meski ada juga komoditi yang mengalami peningkatan meski subsidinya dihapus, namun kebijakan ini merugikan sektor pertanian secara agregat, (3) meski terjadi peningkatan kesejahteraan masyarakat di seluruh negaranamun bila hambatan perdagangan dihapus secara total maka negara maju adalah kelompok yang paling diuntungkan, (4) dalam konteks Indonesia, maka Indonesia belum sanggup untuk malakukan perdagangan pada tingkat tarif nol. Sektor dan komoditas strategis masih perlu dilindungi agar bisa berkembang Indonesia memerlukan waktu untuk meningkatkan dayasaing.
Hortikultura saat ini menjadi komoditas yang menguntungkan karena pertumbuhan ekonomi yang semakin meningkat turut memicu peningkatan konsumsi hortikultura seiring dengan peningkatan pendapatan masyarakat. Menurut Saptana et al. (2006), komoditas hortikultura tergolong sebagai komoditas komersial bernilai ekonomi tinggi (high value commodity), sehingga harus diproduksi secara efisien untuk dapat bersaing di pasar.

Hortikultura merupakan kelompok komoditas yang penting dan strategis tersedia dalam jumlah yang cukup dengan mutu yang layak, aman dikonsumsi, dan dengan harga yang terjangkau oleh masyarakat. Pasar hortikultura di dunia sangat besar dan menunjukkan kecenderungan yang semakin meningkat sejalan dengan peningkatan laju pertumbuhan penduduk.

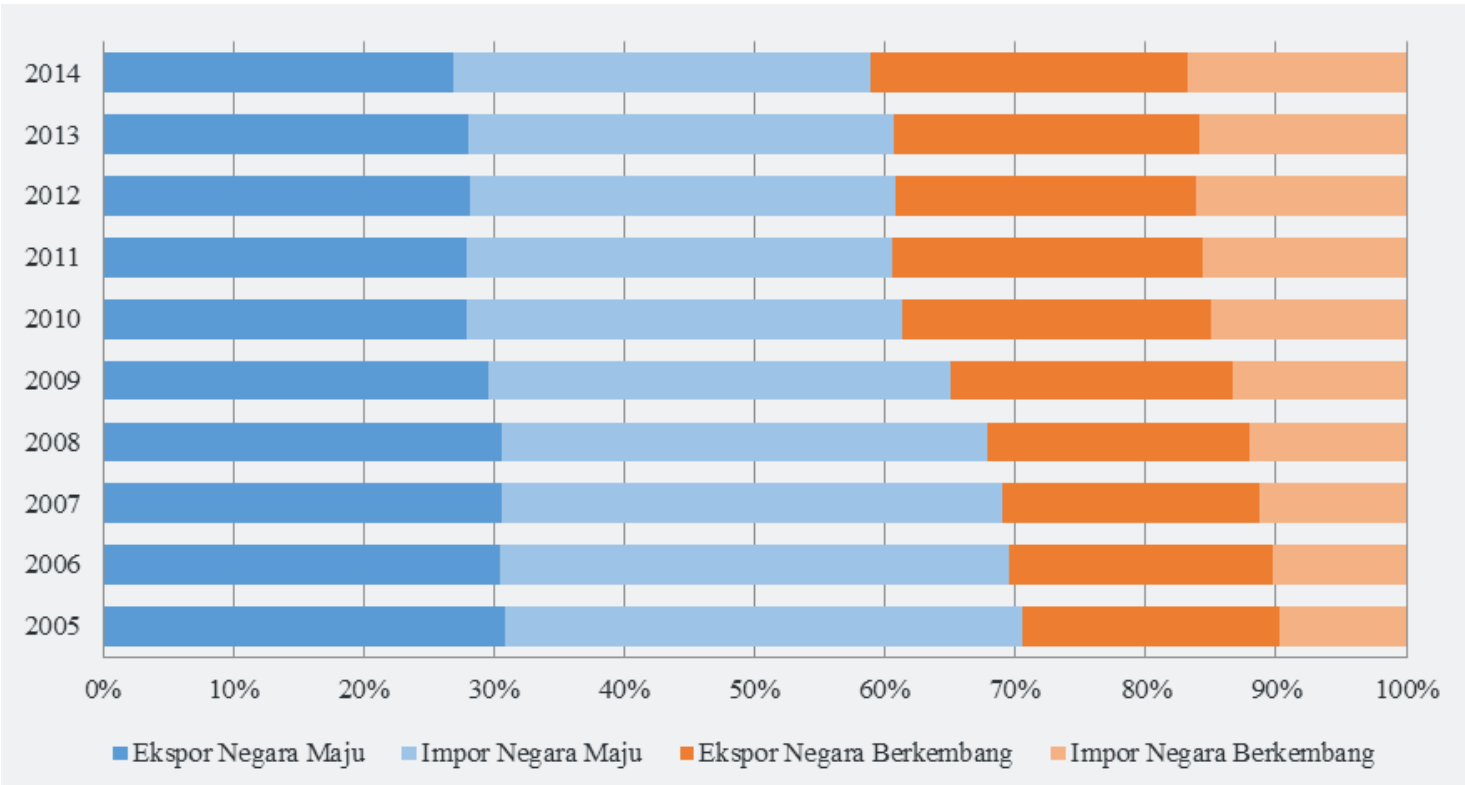

Sumber: UN Comtrade, 2015 (diolah)

Gambar 1 Nilai ekspor impor komoditas hortikultura dunia tahun 2005-2014 (juta US dollar)

Produk hortikultura merupakan sumber yang semakin penting dari pendapatan ekspor bagi banyak negara berkembang. Gambar 1 menunjukkan perbandingan rata-rata pertumbuhan nilai ekspor dari tahun 2005-2014, 
negara berkembang dengan rata-rata per-tumbuhannya sebesar $69,81 \%$ masih lebih tinggi dibandingkan rata-rata pertumbuhan negara maju $(40,78 \%)$ dan dunia $(52,09 \%)$. Hal ini menunjukkan bahwa komoditas hortikultura merupakan komoditas ekspor yang potensial bagi negara berkembang dalam perdagangan internasional. Peningkatan ekspor pertaniannontradisional, seperti ekspor hortikultura, di negara-negara berkembang tidak hanya akan menyebabkan ekspansi pendapatan devisa yang digunakan untuk memenuhi meningkatnya impor komoditas lain, tetapi juga untuk memenuhi meningkatnya pembayaran utang. Dengan demikian, negara-negara berkembang harus menemukan potensi ekspor non-tradisional pada saat pertumbuhan pasar tradisional mengalami penurunan.

Perdagangan produk pertanian juga dihadapkan pada masalah volatilitas harga dan berbagai hambatan perdagangan seperti hambatan tarif dan hambatan non tarif. Selama krisis harga pangan tahun 2008-2009, harga pasar produk pertanian dunia dan makanan meningkat tajam dan meningkatkan volatilitas harga pertanian di tahuntahun berikutnya. Selain itu, dengan semakin berkembangnya globalisasi dan liberalisasi perdagangan juga akan memberikan peluang sekaligus tantangan baru dalam pembangunan pertanian kedepan khususnya komoditas hortikultura.

Pasar komoditas yang semakin luas sejalan dengan dihapuskannya berbagai hambatan perdagangan antar negara dapat memberikan peluang dalam pembangunan pertanian ini. Namun liberalisasi perdagangan juga dapat menimbulkan masalah jika komoditas yang diproduksi secara lokal tidak mampu bersaing dengan negara lain sehingga pasar domestik semakin dibanjiri oleh komoditas impor, yang pada gilirannya akan merugikan petani. Oleh karena itu peningkatan daya saing merupakan tuntutan yang tak bisa dihindari dalam pelaksanaan pembangunan pertanian di masa yang akan datang. Berdasarkan uraian tersebut, maka penelitian ini menganalisis dayasaing komoditas hortikultura negara berkembang dan maju di pasar internasional serta faktor-faktor apa saja yang mempengaruhi aliran perdagangan komoditas hortikultura di pasar internasional.

\section{METODE PENELITIAN}

Data yang digunakan dalam penelitian ini merupakan data sekunder yang diperoleh dari berbagai sumber, antara lain FAO, WDI, WTO, Comtrade, dan CEPII. Komoditas holtikultura yang dianalisis dayasaingnya yaitu potatoes, fresh or chilled nes (HS. 070190); cabbages (HS. 070490); bananas, including plantains, fresh or dried (HS. 080300); pineapples, fresh or dried (HS. 080430); guavas, mangoes and mangosteens, fresh or dried (HS. 080450); dan ginger (HS. 091010). Estimasi analisis regresi model grafity menggunakan data panel tahunan periode 2004-2013 terdiri dari 3 negara maju yaitu Portugal, Amerika Serikat dan Australia serta 3 negara berkembang yaitu China, India, dan Indonesia dengan jumlah negara tujuan ekspor 5 sampai dengan 20 negara.

Metode analisis yang digunakan dalam penelitian ini adalah metode analisis deskriptif dan kuantitatif. Metode deskriptif digunakan untuk menggambarkan perkembangan nilai ekspor hortikultura di pasar internasional serta menganalisis datadata yang digunakan dalam penelitian ini. Metode kuantitatif yang digunakan 
menganalisis keunggulan komparatif komoditi hortikultura negara berkembang dan negara maju serta antar sesama negara berkembang adalah menggunakan Revealed Comparative Advantage (RCA), sedangkan metode Export Product Dynamic (EPD) digunakan untuk mengetahui posisi dayasaing berdasarkan performa ekspor hortikultura. Pengolahan data pada penelitian ini dilakukan secara bertahap, tahap pertama yaitu pengelompokan data, tahap kedua yaitu pengolahan data dalam RCA dan EPD serta model gravity.

\section{Revealed Comparatif Advantage (RCA)}

Indeks RCA atau biasa dikenal sebagai indeks Balassa (1989) adalah indikator yang dapat menggambarkan keunggulan komparatif (tingkat dayasaing) komoditas suatu negara di pasar global. Jika nilai indeks RCA yang diperoleh adalah lebih dari satu (RCA $>1$ ), maka negara bersangkutan memiliki keunggulan komparatif di atas rata-rata dunia untuk komoditas tersebut. Indeks RCA dapat dirumuskan sebagai berikut:

$\mathrm{RCA}=\frac{\mathrm{Xij} / \mathrm{Xj}}{\mathrm{Xiw} / \mathrm{Xw}}$

Dimana,

$$
\begin{aligned}
\mathrm{X}_{\mathrm{ij}}= & \text { nilai ekspor negara } \mathrm{j} \text { untuk } \\
& \text { komoditas } \mathrm{i} \text { ke dunia (US\$) } \\
\mathrm{X}_{\mathrm{j}}= & \text { nilai total ekspor negara } \mathrm{j} \text { ke } \\
& \text { dunia (US\$) } \\
\mathrm{X}_{\mathrm{iw}}= & \text { nilai ekspor dunia untuk } \\
& \text { komoditas } \mathrm{i}(\mathrm{US} \$ \text { ) } \\
\mathrm{X}_{\mathrm{w}}= & \text { nilai total ekspor dunia (US\$) }
\end{aligned}
$$

\section{Export Product Dynamic (EPD)}

Export Product Dynamics (EPD) adalah indikator yang mengukur posisi pasar dari produk suatu negara untuk tujuan pasar tertentu. Selain itu, dengan EPD, dinamis atau tidaknya performa suatu produk dapat diketahui.

Sumbu $\mathrm{x}$ : Pertumbuhan pangsa pasar ekspor suatu negara

$\frac{\sum_{\mathrm{t}=1}^{\mathrm{n}}\left(\frac{\mathrm{Xij}}{\mathrm{Xiw}}\right)_{\mathrm{t}} \mathrm{x} 100 \%-\sum_{\mathrm{t}=1}^{\mathrm{n}}\left(\frac{\mathrm{Xij}}{\mathrm{Xiw}}\right)_{\mathrm{t}-1} \mathrm{x} 100 \%}{\mathrm{~T}}$

Sumbu y: Pertumbuhan pangsa pasar komoditas di perdagangan dunia

$$
\frac{\sum_{\mathrm{t}=1}^{\mathrm{n}}\left(\frac{\mathrm{Xj}}{\mathrm{Xw}}\right)_{\mathrm{t}} \mathrm{x} 100 \%-\sum_{\mathrm{t}=1}^{\mathrm{n}}\left(\frac{\mathrm{Xj}}{\mathrm{Xw}}\right)_{\mathrm{t}-1} \mathrm{x} 100 \%}{\mathrm{~T}}
$$

Keterangan:

$\mathrm{X}_{\mathrm{ij}}=$ nilai ekspor komoditas $\mathrm{i}$ dari negara $\mathrm{j}$ ke dunia (US\$)

$\mathrm{X}_{\mathrm{j}}=$ nilai total ekspor negara $\mathrm{j} \mathrm{ke}$ dunia (US\$)

$\mathrm{X}_{\mathrm{iw}}=$ nilai ekspor dunia untuk komoditas i (US\$)

$\mathrm{X}_{\mathrm{w}}=$ nilai total ekspor dunia (US\$)

$\mathrm{T}=$ Jumlah tahun analisis yang dipergunakan

Tabel 1 Matriks posisi pasar

\begin{tabular}{lcc}
\hline \multicolumn{1}{c}{ Shae of country's export in } & \multicolumn{2}{c}{ Share of product in world trade $(y)$} \\
\cline { 2 - 3 } world trade $(x)$ & Rising/Dynamic $(+)$ & Falling/Stagnant (-) \\
\hline Rising/Competitive (+) & Rising start & Falling stars \\
Falling/non-competitive (-) & Lost Opportunity & Retreat \\
\hline
\end{tabular}

Sumber: Estherhuizen 2006

Posisi pasar yang ideal adalah yang mempunyai pangsa pasar tinggi pada ekspornya sebagai rising star yang menunjukkan bahwa negara tersebut memperoleh tambahan pangsa pasar pada produk mereka yang bertumbuh cepat (fast-growing product). Lost opportunity, terkait dengan penurunan pangsa pasar pada produk-produk yang dinamis, adalah posisi yang paling tidak 
diinginkan. Falling star juga tidak disukai, meskipun masih lebih baik jika dibandingkan dengan lost opportunity, karena pangsa pasarnya tetap meningkat. Sementara itu, retreat biasanya tidak diinginkan, tetapi pada kasus tertentu mungkin diinginkan jika pergerakannya menjauhi produk-produk yang stagnan dan menuju produkproduk yang dinamik.

\section{Gravity Model}

Gravity model menampilkan analisis empiris dari pola aliran perdagangan bilateral antara negaranegara yang berada pada daerah-daerah yang berbeda secara geografis. Gravity model pertama kali digunakan dalam analisis perdagangan internasional oleh Jan Tinberger pada tahun 1962 untuk menganalisis aliran perdagangan antara negara-negara Eropa.

Model ini didasarkan pada hukum gravitasi Newton, yang menyatakan bahwa gaya gravitasi antara dua benda secara langsung dipengaruhi secara proporsional oleh massa dari kedua benda tersebut dan sebaliknya secara proporsional dipengaruhi oleh jarak kuadrat antara keduanya. Pada gravity model aliran perdagangan bilateral ditentukan oleh tiga kelompok variabel, yaitu:

- Variabel-variabel yang mewakili total permintaan potensial negara pengimpor.

- Variabel-variabel indikator total penawaran potensial negara pengekspor.

- Variabel-variabel pendukung atau penghambat aliran perdagangan antara negara pengimpor dan negara pengekspor.

Secara umum, Gravity model dapat digambarkan seperti berikut:

$$
X_{i j}=A \frac{Y_{i} Y_{j}}{D_{i j}}
$$

Dimana:

$\mathrm{X}_{\mathrm{ij}} \quad=$ Ekspor

$\mathrm{Y} \quad=$ Pendapatan Nasional (GDP); $\mathrm{Y}_{\mathrm{i}}$ adalah GDP untuk negara i dan $\mathrm{Y}_{\mathrm{j}}$ untuk negara $\mathrm{j}$

$\mathrm{D}_{\mathrm{ij}} \quad=$ Jarak geografis antara kedua negara

Model gravity kemudian dikembangkan dengan mengestimasi menggunakan data panel, dimana model fixed effect dalam penelitiannya tersebut digunakan untuk mengestimasi dampak pembatasan impor terhadap ekspor dengan menambahkan indikator trade policy. Model gravity yang diperluas tersebut dituliskan sebagai berikut:

$$
\begin{aligned}
\ln X_{i j t}=\alpha+ & \beta \ln Y_{i t}+\gamma \ln Y_{j t} \\
& -\delta \ln D_{i j}+\lambda T_{j t}+\varepsilon_{i j t}
\end{aligned}
$$

Ket:

$\mathrm{X}=$ Ekspor

$\mathrm{Y}=$ Pendapatan Nasional (GDP)

$\mathrm{D}=$ Jarak Ekonomi

$\mathrm{T}=$ Trade Policy Index

I $=$ Negara pengekspor

$\mathrm{J}=$ Negara pengimpor

$\mathrm{T}=$ Tahun yang akan menjadi model rujukan untuk penelitian.

\section{Estimasi Model}

Metode yang digunakan untuk menganalisis tujuan ketiga dalam penelitian ini adalah Gravity Model dimana model ini telah secara luas digunakan untuk mengukur potensi perdagangan dan dampak dari penerapan suatu kebijakan perdagangan. Pada dasarnya, model ini dapat merepresentasikan kekuatan permintaan dan penawaran. Formula standar gravity model secara spesifik menerangkan aliran perdagangan antara Negara $\mathrm{i}$ dan $\mathrm{j}$ berdasarkan tiga faktor. Pertama, model telah mencakup indikasi potensi penawaran dari negara eksportir (i). Kedua, model dapat mengakomodasi potensi permintaan dari negara importir 
(j), dan poin ketiga mencakup faktorfaktor yang berkaitan dengan hambatan aliran perdagangan. Berdasarkan penelitian Dahar (2014) secara empiris mengkonfirmasi bahwa pendapatan perkapita negara pengimpor, populasi negara pengimpor, dan jarak ekonomi merupakan faktor yang dapat mempengaruhi perdagangan ekspor hortikultura Indonesia. SPS dan TBT baik dengan menggunakan pendekatan coverage ratio maupun frequency index berpengaruh negatif pada ekspor hortikultura Indonesia ke negara ASEAN +3.

Untuk menjawab masalah dalam penelitian ini, spesifikasi model yang digunakan dalam penelitian mengacu pada gravity model yang digunakan oleh Bhattacharya (2007) yang telah dimodifikasi sebagai berikut:

Ln $\mathrm{EKS}_{\mathrm{ijt}}=\beta_{0}+\beta_{1} \ln \mathrm{R}_{-} \mathrm{GDP}_{\mathrm{jt}}+$ $\beta_{2} \ln \mathrm{P}_{-} \mathrm{EKS}_{\mathrm{ijt}}+\beta_{3} \ln \mathrm{POP}_{\mathrm{jt}}+$ $\beta_{4} \ln$ PROD $_{\mathrm{it}-1}+\beta_{5}$ Tariff $_{\mathrm{jt}}+$ $\beta_{6} \ln$ Ecodist $_{\text {ijt }}+\beta_{7}$ ln R_EXR ${ }_{\text {it }}+$ $\beta_{8} \ln \mathrm{SPS}_{\mathrm{jt}}+\varepsilon_{\mathrm{ijt}}$

keterangan:

\begin{tabular}{|c|c|}
\hline$E_{K S} S_{i j t}$ & $\begin{aligned}= & \text { Volume ekspor } \\
& \text { komoditas hortikultura } \\
& \text { dari negara eksportir (i) } \\
& \text { ke negara importir (j) } \\
& \text { pada tahun } \mathrm{t}(\mathrm{Kg})\end{aligned}$ \\
\hline R_GDP ${ }_{j t}$ & $\begin{aligned} &= \text { GDP riil perkapita negara } \\
& \text { importir pada tahun } t \\
&(\mathrm{US} \$)\end{aligned}$ \\
\hline$P_{-} E_{K S} S_{i j t}$ & $\begin{aligned}= & \text { Harga ekspor komoditas } \\
& \text { hortikultura di negara } \\
& \text { eksportir pada tahun t } \\
& (\mathrm{US} \$ / \mathrm{Kg})\end{aligned}$ \\
\hline
\end{tabular}

\begin{tabular}{|c|c|}
\hline $\mathrm{POP}_{\mathrm{jt}}$ & $\begin{aligned}= & \text { Populasi negara importir } \\
& \text { pada tahun } \mathrm{t} \text { (Jiwa) }\end{aligned}$ \\
\hline PROD $_{\mathrm{it}-1}$ & $\begin{aligned}= & \text { Produksi komoditi } \\
& \text { hortikultura pada tahun } \\
& \text { sebelumnya (Ton) }\end{aligned}$ \\
\hline Tariff $_{\mathrm{jt}}$ & $\begin{aligned}= & \text { Tarif ad valorem } \\
& \text { komoditas hortikultura di } \\
& \text { negara importir pada } \\
& \text { tahun } \mathrm{t}(\%)\end{aligned}$ \\
\hline Ecodist $_{i j t}$ & $\begin{aligned} &= \text { Jarak Ekonomi antar } \\
& \text { negara eksportir dan } \\
& \text { importir pada tahun } t \\
& \text { (dalam satuan km yang } \\
& \text { telah dibobot dengan share } \\
& \text { GDP masing-masing } \\
& \text { Negara partner) }\end{aligned}$ \\
\hline R_EXR ${ }_{i t}$ & $\begin{aligned} &= \text { Nilai tukar riil mata uang } \\
& \text { negara eksportir terhadap } \\
& \text { dolar Amerika pada tahun } \\
& \\
& \mathrm{t}(\text { LCU/US\$) }\end{aligned}$ \\
\hline $\mathrm{SPS}_{\mathrm{jt}}$ & $\begin{aligned} &= \text { Jumlah Sanitary and } \\
& \text { Phytosanitary (SPS) } \\
& \text { komoditas hortikultura } \\
& \text { yang diterapkan di negara } \\
& \text { importir pada tahun t } \\
& \text { (Unit) }\end{aligned}$ \\
\hline$\beta_{0}$ & $=$ Konstanta/Intersep \\
\hline $\begin{array}{l}\beta 1, \beta 2, \beta 3, \\
\beta 4, \beta 5 \\
\beta_{6}, \beta_{7}, \beta_{8}\end{array}$ & $=$ Parameter yang diestimasi \\
\hline$\varepsilon_{\mathrm{ijt}}$ & $=$ Error term \\
\hline $\mathrm{i}$ & $=$ Negara asal ekspor \\
\hline $\mathrm{j}$ & $=$ Negara tujuan ekspor \\
\hline $\mathrm{t}$ & $\begin{aligned} &= \text { Tahun yang akan menjadi } \\
& \text { model rujukan untuk } \\
& \text { penelitian }\end{aligned}$ \\
\hline
\end{tabular}


1. Liberalisasi sektor pertanian (WTO)

2. Pangsa pangsa ekspor komoditas hortikultura negara berkembang meningkat

3. Pertumbuhan peduduk dan meningkatnya pendapatan

4. Komoditas hortikultura merupakan komoditas komersial bernilai ekonomi tinggi (high value commodity)

1. Permintaan komoditas hortikultura semakin meningkat

2. Volatilitas harga komoditas hortikultura dan kebijakan tarif perdagangan

3. Produk hortikultura domestik harus mampu bersaing produk impor

4. Ketahanan pangan

\section{Tujuan Penelitian:}

1. Menganalisis daya saing komoditas hortikultura di pasar internasonal.

2. Mengidentifikasi faktor-faktor yang mempengaruhi ekspor komoditas hortikultura.

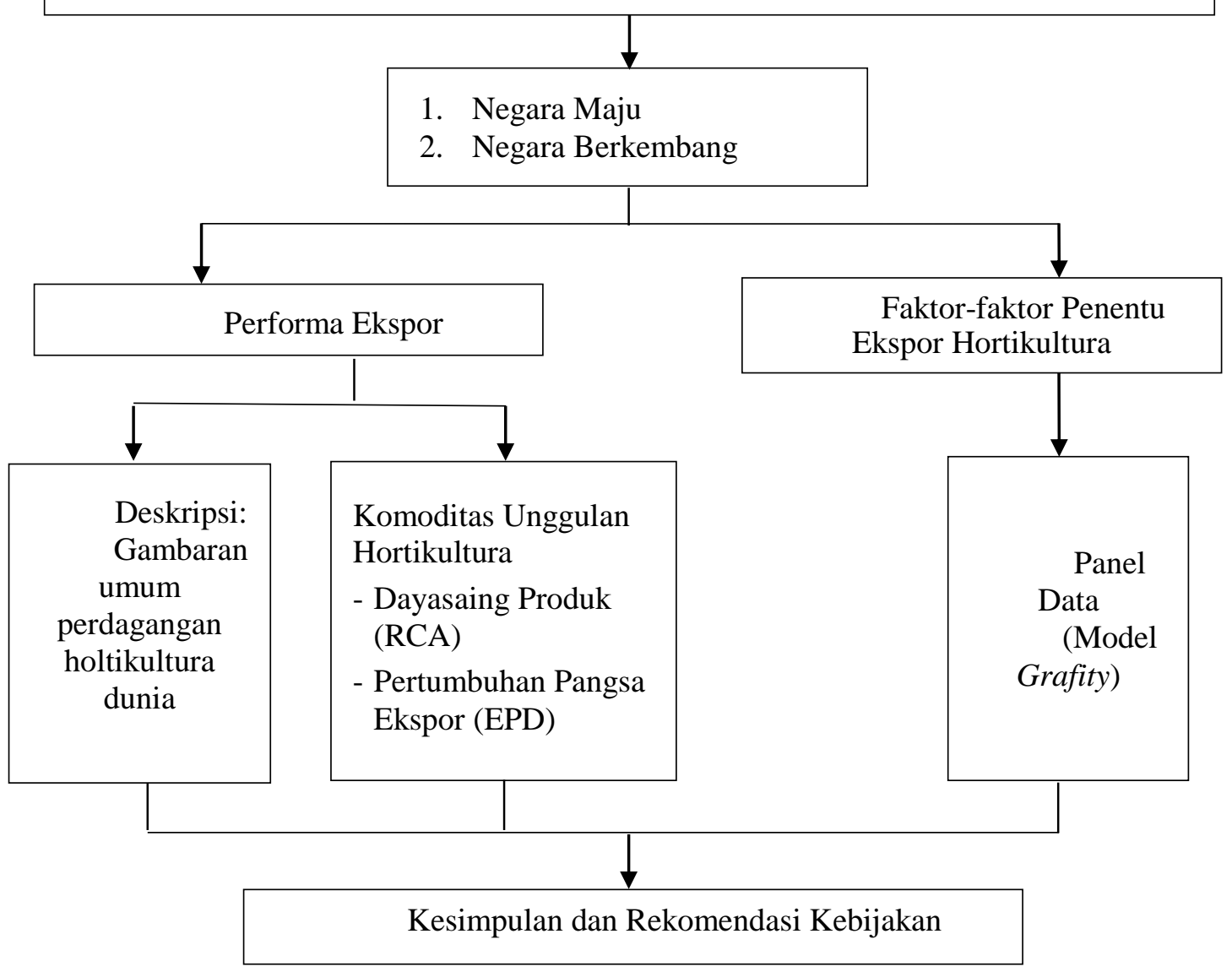

Gambar 2 Kerangka Pemikiran Operasional 


\section{HASIL DAN PEMBAHASAN}

\section{Analisis Daya Saing Komoditas Hortikultura}

Berdasarkan pengelompokannnya, hortikultura terbagi atas empat kelompok yaitu tanaman hias, sayuran, buahbuahan dan tanaman biofarmaka. Secara agregat, produk hortikultura yang terdiri dari tanaman hias (HS 06), sayursayuran (HS 07), buah-buahan (HS 08) dan biofarmaka (HS 0910) mengalami kenaikan dalam hal nilai ekspornya. Dalam kurun waktu 9 (sembilan) tahun yaitu antara 2005 sampai dengan 2013, nilai ekspor hortikultura dunia mengalami peningkatan dari tahun ke tahun, hanya pada tahun 2009 dan tahun 2012 mengalami penurunan. Rata-rata pertumbuhan nilai ekspor hortikultura dunia adalah sebesar 9,18\%.

Tabel 2 Perkembangan neraca perdagangan hortikultura dunia tahun 2009-2014 (ribu US\$)

\begin{tabular}{lccrcrr}
\hline \multirow{2}{*}{ Neraca Perdagangan } & \multicolumn{6}{c}{ Tahun } \\
& 2009 & \multicolumn{1}{c}{2010} & \multicolumn{1}{c}{2011} & \multicolumn{1}{c}{2012} & \multicolumn{1}{c}{2013} & \multicolumn{1}{c}{2014} \\
\hline Dunia & $-275,861$ & $-188,082$ & $-171,996$ & $-135,598$ & $-32,103$ & $-80,749$ \\
Negara Maju & $-601,976$ & $-647,659$ & $-824,410$ & $-783,697$ & $-547,554$ & $-634,233$ \\
Negara Berkembang & 303,373 & 483,992 & 601,533 & 592,695 & 575,081 & 598,372 \\
\hline
\end{tabular}

Sumber: UN Comtrade, 2015 (diolah)

Neraca perdagangan pada komoditi hortilultura secara agregat dari tahun 2009 sampai dengan 2013 masih menunjukkan tren defisit neraca perdagangan yang relatif besar. Berdasarkan data UNComtrade, hanya neraca perdagangan hortikultura negara berkembang yang bernilai positif, untuk dunia dan negara maju bernilai negatif. Artinya, nilai ekspor komoditi tersebut mempunyai nilai lebih kecil dibandingkan nilai impornya.

Neraca perdagangan komoditi tersebut jika dilihat pada Tabel 2, dari tahun 2008 sampai dengan 2013, nilai surplus negara berkembang semakin membesar yaitu dari surplus US \$303 ribu pada tahun 2009 menjadi surplus US \$ 598 ribu pada tahun 2013. Hal ini menunjukkan kebutuhan akan komoditi ini meningkat setiap tahunnya bahkan untuk kebutuhan dunia mengalami defisit.

Pada gambar 3 menunjukkan ratarata nilai ekspor komoditas hortikultura dunia tahun 2005-2014 dengan rata-rata nilai ekspor terbesar adalah buahbuahan yang mencapai US\$ 55,24 juta pada periode 2005 - 2009, meningkat menjadi US\$ 71,16 juta selama periode 2010 - 2014. Produk lainnya (tanaman hias, sayuran dan biofarmaka) memberikan kontribusi sebesar 53\% terhadap ekspor hortikultura dunia pada periode 2009 - 2014.

Keunggulan komparatif merupakan salah satu faktor penentu dayasaing suatu komoditi di pasar tujuan ekspor. Analisis keunggulan komparatif digunakan karena nilai ekspor yang tinggi bukan merupakan suatu acuan utama apakah suatu komoditi memiliki performa yang baik di pasar tujuan. Untuk memperkuat argumen tingkat kinerja ekspor komoditi hortikultura, penelitian ini menggunakan analisis pendekatan nilai Revealed Comparative Advantage (RCA) dan nilai Export Product Dynamic (EPD) sebagai pengukur dayasaing ekspor komoditi hortikultura negara eksportir di pasar dunia. 
Dengan kombinasi perhitungan RCA dan EPD, maka kinerja ekspor komoditas hortikultura antar negara di pasar dunia dapat diketahui kekuatan dayasaing dan dinamis atau tidaknya performa suatu produk. Berdasarkan hasil analisis dayasaing posisi pasar pada matriks EPD, terdapat dua komoditi yang memenuhi kriteria sebagai komoditi ekspor hortikultura di pasar dunia yang dinamis yaitu pisang dan nanas, serta tiga komoditi ekspor hortikultura di pasar dunia yang tidak dinamis yaitu kentang, kubis, dan jambu mangga manggis.

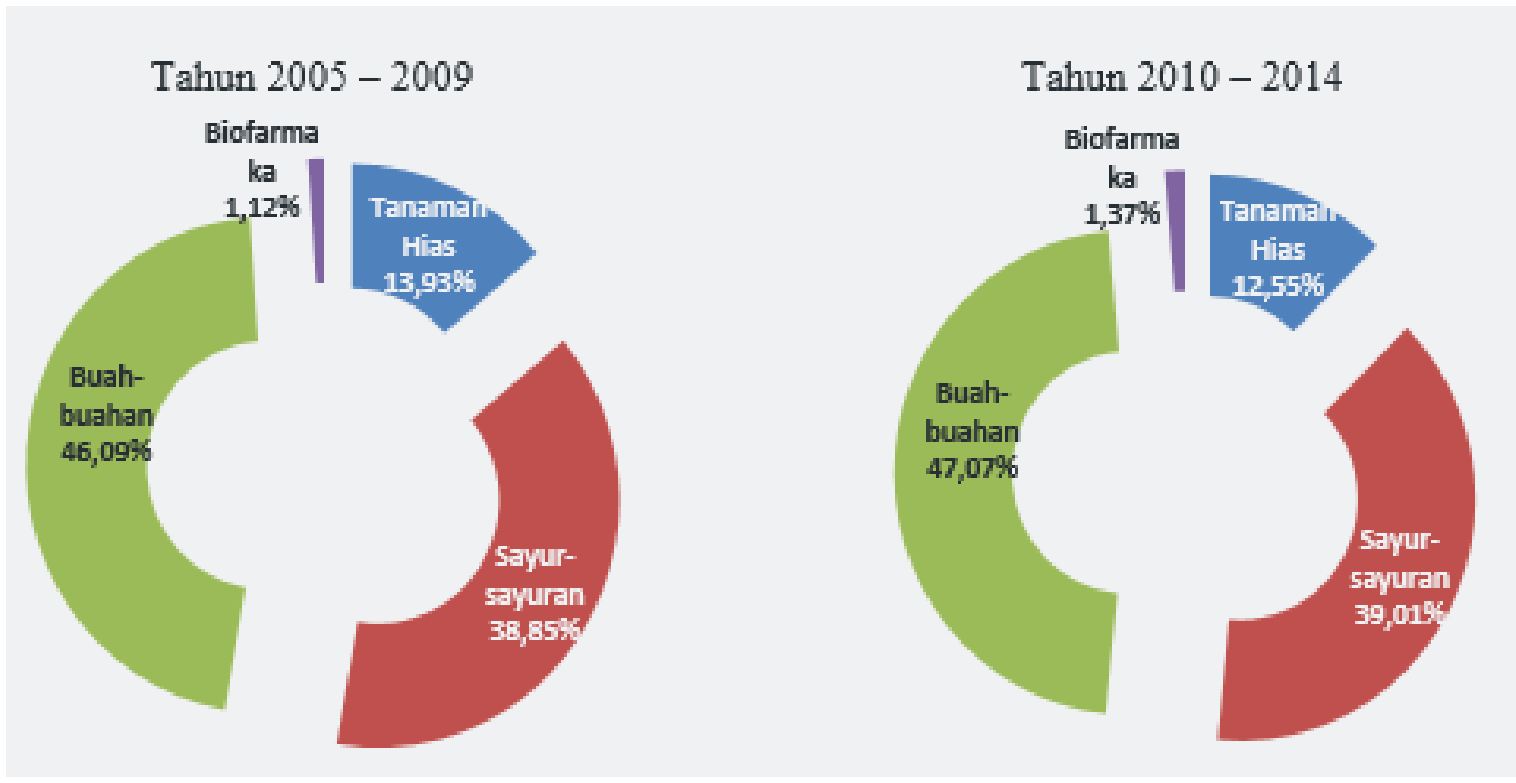

Sumber: UN Comtrade, 2015 (diolah)

Gambar 3 Komposisi rata-rata nilai ekspor komoditas hortikultura dunia tahun 20052014

\section{Daya Saing Kentang}

Kentang merupakan sumber karbohidrat sebagian besar negara di dunia khususnya di negara maju. Ratarata total produksi kentang dunia tahun 2007-2013 sebesar 349 juta ton, di mana penyumbang produksi terbesar dunia adalah kawasan Asia sebesar 160 juta ton atau sebesar $45,89 \%$ dari total produksi dunia. Namun jika dilihat dari share ekspor terhadap produksi, maka kawasan Eropa merupakan kawasan dengan rata-rata ekspor terbesar yaitu 6,51 ton per tahun $(67,07 \%$ ekspor dunia) atau rata-rata share ekspor terhadap produksi selama tujuh tahun sebesar 5,4\% (tertinggi di pasar dunia).

Berdasarkan hasil perhitungan RCA, maka terdapat 32 negara yang memiliki daya saing yang kuat (nilai RCA > 1) dan 95 negara yang memiliki dayasaing yang lemah. Dari 32 negara dengan dayasaing kuat, 27 negara merupakan negara berkembang dan 5 negara merupakan negara maju. Hasil perhtungan EPD menunjukan bahwa komoditi kentang bukan pasar yang dinamis di pasar dunia.

Hasil perhitungan kombinasi RCA dan EPD menunjukkan 12 negara yang mempunyai dayasaing ekspor kentang yang kuat dan berada pada posisi falling stars di pasar dunia, yang terdiri dari 11 negara maju dan hanya satu negara berkembang yaitu Kolombia. 


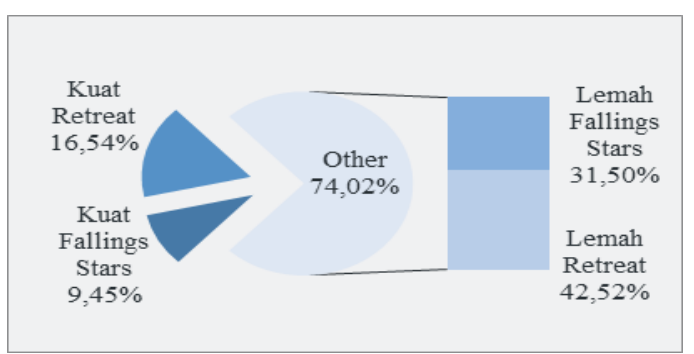

Gambar 4 Hasil nilai RCA dan EPD kentang antar negara di pasar dunia periode 20042013

Berdasarkan hasil perhitungan RCA komoditi kentang dalam persaingan antar sesama negara berkembang, terdapat 26 negara dengan dayasaing ekspor yang kuat dan 65 negara berkembang dengan dayasaing ekspor kentang yang lemah. Hasil perhitungan kombinasi RCA dan EPD menujukkan terdapat 6 negara berkembang yang mempunyai nilai RCA > 1 dan berada pada posisi falling stars.

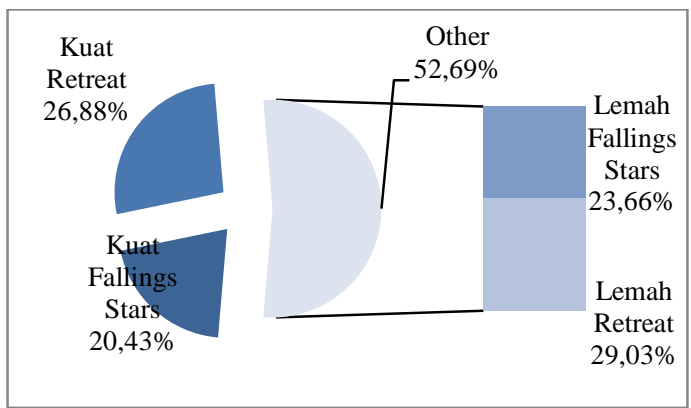

Gambar 5 Hasil nilai RCA dan EPD kentang antar sesama negara berkembang periode 20042013

\section{Dayasaing Kubis}

Kubis merupakan salah satu sayuran yang potensial untuk dikembangkan dalam perdagangan internasional. Rata-rata ekspor kubis dunia sebesar 1,65 juta ton per tahun atau hanya sekitar $2,45 \%$ dari rata-rata total produksi kubis dunia. Hasil perhitungan EPD menunjukkan bahwa pangsa pasar komoditi kubis dunia berada pada pertumbuhan yang tidak dinamis.

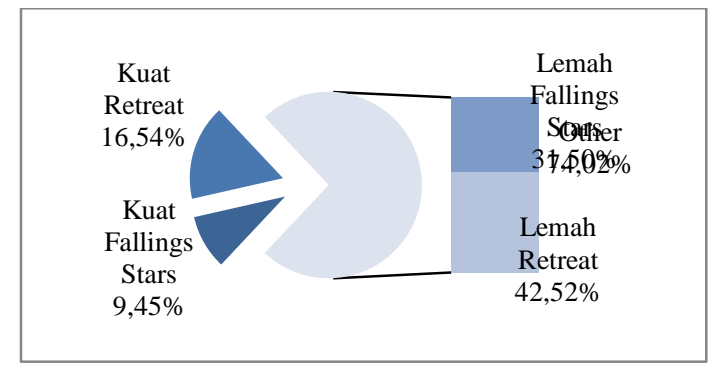

Gambar 6 Hasil nilai RCA dan EPD kubis antar negara di pasar dunia periode 2004-2013

Dalam persaingan ekspor komoditi kubis di pasar dunia, terdapat 12 negara yang berada pada posisi falling stars dan mempunyai dayasaing ekspor yang kuat, di mana 11 diantaranya merupakan negara berkembang dan hanya satu negara maju yaitu Spanyol. Sedangkan untuk persaingan antar sesama negara berkembang, dari 93 negara berkembang ekspotir kubis hanya 19 negara berkembang saja yang berada pada posisi falling stars dan mempunyai dayasaing ekspor kubis yang kuat di pasar dunia.

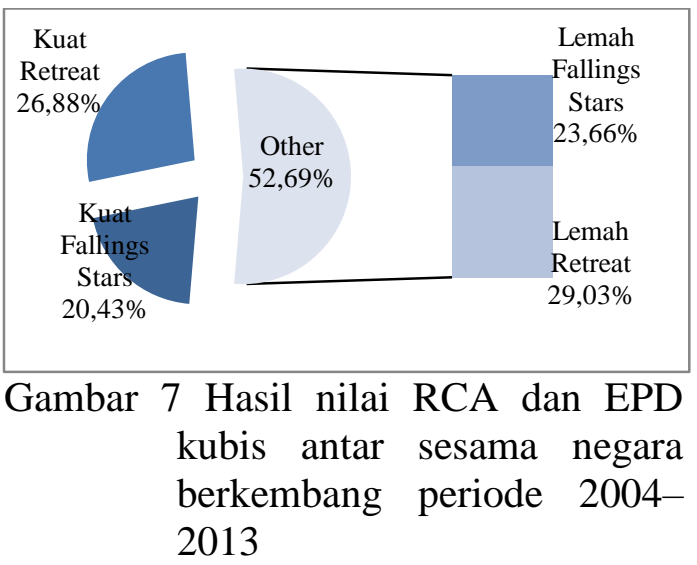

\section{Dayasaing Pisang}

Jumah negara eksportir pisang adalah 127 negara terbagi menjadi 93 negara berkembang dan 34 negara maju. 
Pisang merupakan buah-buahan yang potensial bagi perdagangan di dunia khusunya di kawasan Amerika. Selama tahun 2007-2013, rata-rata volume ekspor pisang terbesar di dunia adalah berada di kawasan Amerika yaitu sekitar 13,231 juta ton per tahun dengan shared ekspor terhadap produksi sebesar $49,08 \%$ per tahun.

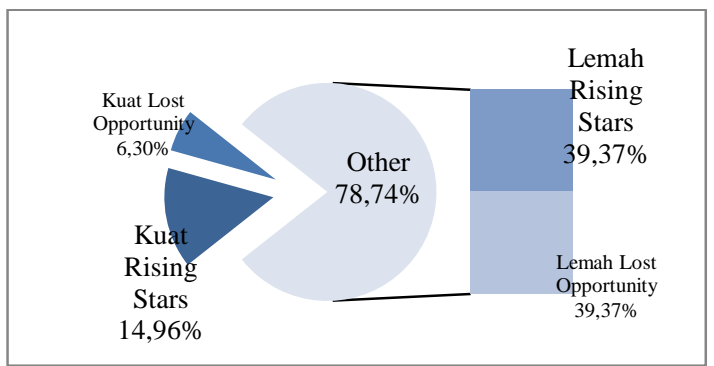

Gambar 8 Hasil nilai RCA dan EPD pisang antar negara di pasar dunia periode 2004-2013

Jika dilihat dari hasil perhitungan RCA ekspor komoditi pisang antar negara di pasar dunia, maka hanya sekitar $20,5 \%$ yang mempunyai nilai RCA lebih dari satu atau sekitar 26 negara, yaitu 22 negara berkembang dan empat negara maju. Sedangkan dalam persaingan antar sesama negara berkembang, terdapat 44 negara berkembang yang memiliki nilai RCA lebih dari satu. Untuk posisi pasar dunia, terdapat 69 negara $(54,3 \%)$ yang mempunyai posisi rising stars dan 58 negara berada pada posisi lost opportunity.

Berdasarkan hasil analisis menggunakan perhitungan RCA dan EPD, maka hanya ada sekitar $15 \%$ atau 19 negara eksportir di dunia yang mepunyai dayasaing kuat dan posisinya berada pada rising stars, di mana $89 \%$ merupakan negara berkembang atau sebanyak 19 negara berkembang. Sedangkan dalam persaingan antar sesama negara berkembang, terdapat 19 negara berkembang dengan posisi rising stars dan mempunyai dayasaing yang kuat.

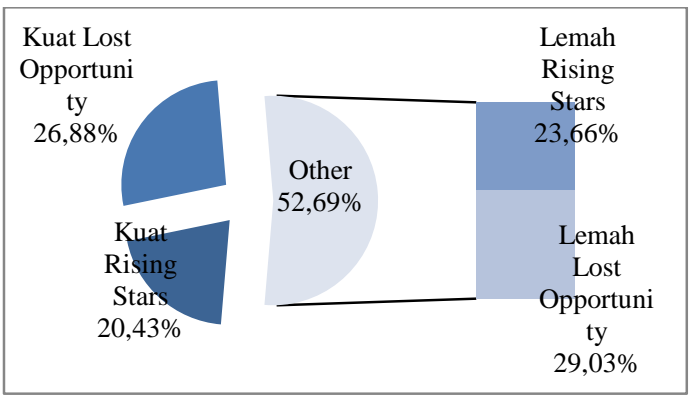

Gambar 9 Hasil nilai RCA dan EPD pisang antar sesama negara berkembang periode 20042013

\section{Dayasaing Nanas}

Nanas merupakan komoditi ekspor hortikultura unggulan di negara berkembang. Sepuluh negara produsen nanas terbesar dunia merupakan negara berkembang, lima negara di kawasan Asia, empat negara di kawasan Amerika dan satu negara yaitu Nigeria berada di kawasan Afrika.

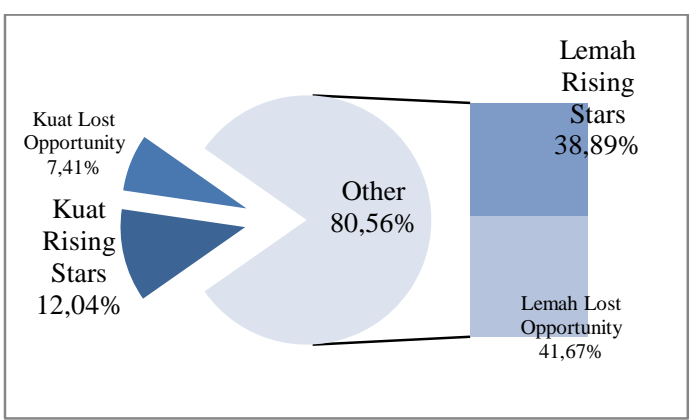

Gambar 10 Hasil nilai RCA dan EPD nanas antar negara di pasar dunia periode 2004-2013

Berdasarkan hasil perhitungan RCA dan EPD, terdapat 13 negara eksportir nanas di dunia yang mempunyai dayasaing ekspor kuat dan mengalami peningkatan ekspor nanas pada pasar dunia yang dinamis, 12 diantaranya merupakan negara berkembang. 


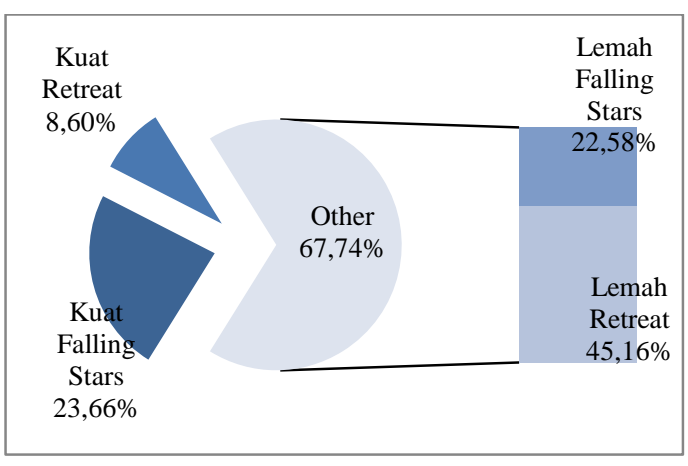

Gambar 11 Hasil nilai RCA dan EPD nanas antar sesama negara berkembang periode 20042013

Untuk persaingan antar sesama negara berkembang, hasil kombinasi perhitungan RCA dan EPD pada komoditi nanas menunjukkan 22 negara berada pada posisi falling stars dan mempunyai dayasaing ekspor nanas yang kuat atau sekitar $23,7 \%$ dari total 93 negara berkembang eksportir nanas.

\section{Dayasaing Jambu, Mangga, dan Manggis}

Produksi jambu mangga manggis terbesar dunia terdapat di kawasan Asia yaitu sebesar 28,84 juta ton per tahun atau sekitar $75,9 \%$ dari total produksi dunia. Namun jika dilihat dari share ekspor terhadap produksi, maka kawasa Amerika merupakan kawasan dengan share ekspor terhadap produksi tertinggi yaitu sebesar 13,32\% per tahun sedangkan di kawasan Asia hanya $2,31 \%$ per tahun. Berdasarkan hasil perhitungan kombinasi RCA dan EPD, terdapat 16 negara yang berada pada posisi falling stars dan mempunyai nilai RCA > 1, terdiri dari 14 negara berkembang dan 2 negara maju.

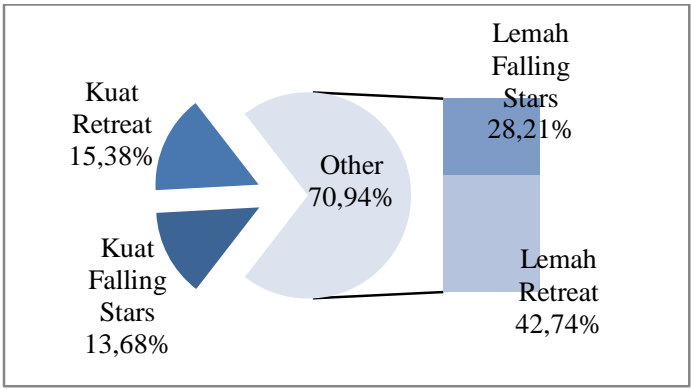

Gambar 12 Hasil nilai RCA dan EPD jambu mangga manggis antar negara di pasar dunia periode 2004-2013

Untuk persaingan antar sesama negara berkembang, terdapat 46 negara berkembang mempunyai nilai RCA > 1 dan 47 negara berkembang dengan nilai RCA < 1 (dayasaing ekspor lemah). Dari 46 negara tersebut, 19 negara berada pada posisi falling stars dan 29 negara berada pada posisi retreat.

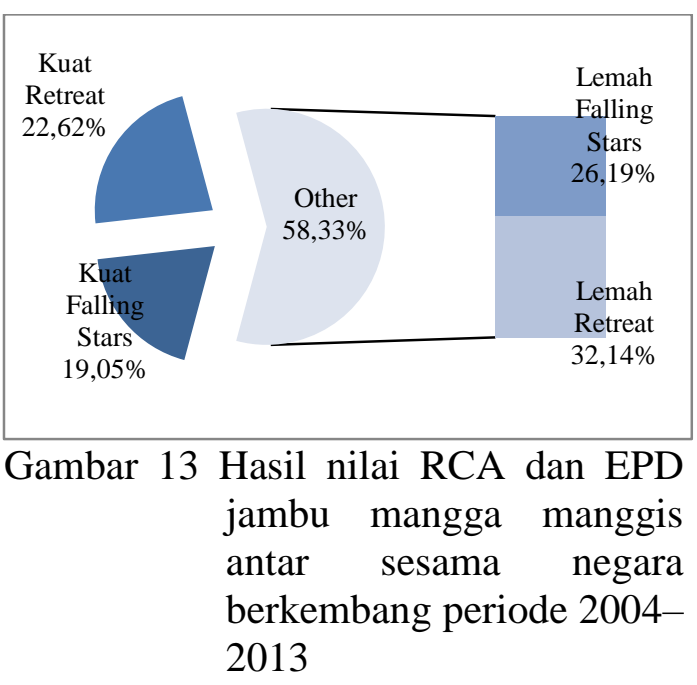

\section{Dayasaing Jahe}

Produksi jahe terbesar dunia terdapat di kawasan Asia yaitu sebesar 1.615 juta ton per tahun dengan ekspor sebesar 550 juta ton per tahun atau sekitar $34,08 \%$ dari shared ekspor terhadap produksi. Berdasarkan hasil perhitungan kombinasi RCA dan EPD, terdapat hanya 14 negara atau $13,9 \%$ yang berada pada posisi falling stars 
dan mempunyai nilai RCA > 1, yang keseluruhannya adalah negara berkembang.

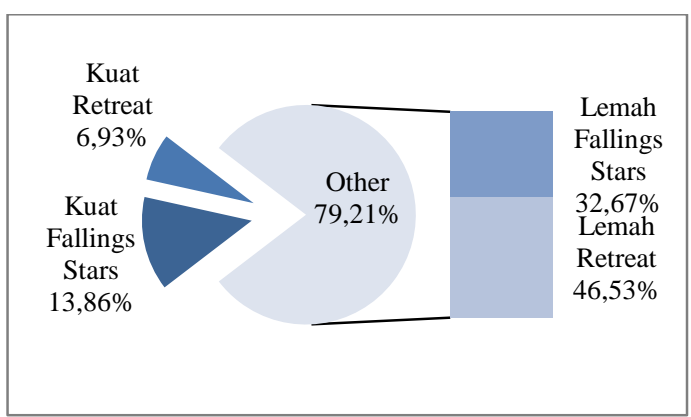

Gambar 14 Hasil nilai RCA dan EPD jahe antar negara di pasar dunia periode 2004-2013

Sedangkan untuk persaingan ekspor jahe antar negara berkembang menunjukkan posisi pasar yang dinamis dengan 15 negara berkembang berdaya saing yang kuat dan berada pada posisi rising star, 7 negara berkembang berdaya saing kuat dan posisi lost opportunity, 25 negara berkembang berdaya saing yang lemah dan berada pada posisi rising star, 22 negara berkembang berdaya saing lemah dan posisi lost opportunity.

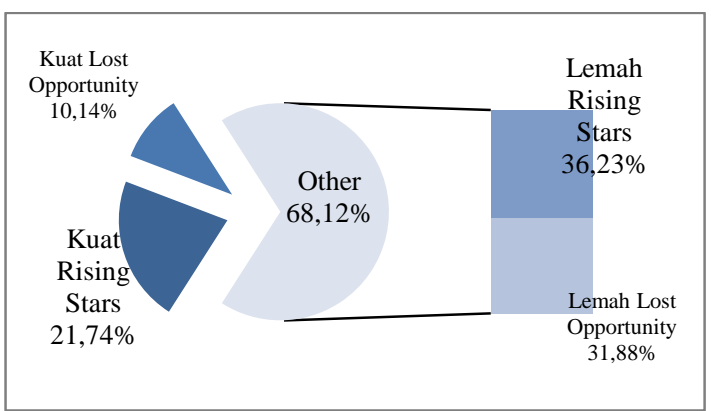

Gambar 15 Hasil nilai RCA dan EPD jahe antar sesama negara berkembang periode 20042013

\section{Faktor-Faktor yang Mempengaruhi Aliran Perdagangan}

Aliran perdagangan komoditi hortikultura di pasar dunia dijelaskan menggunakan model gravity. Model ini digunakan untuk menganalisis pengaruh variabel-variabel ekonomi dan non ekonomi lainnya terhadap aliran perdagangan komoditi ekspor hortikultura di pasar dunia. Dalam analisis aliran perdagangan ini juga telah mewakili dua sisi ekonomi yaitu sisi penawaran diwakili oleh variabel produksi dan harga, sedangkan sisi permintaan diwakili oleh variabel pendapatan, populasi, dan tarif.

Variabel independen yang digunakan dalam analisis aliran perdagangan ini adalah produksi komoditi hortikultura tahun sebelumnya (prod_t_1), harga ekspor (p_eks), pendapatan per kapita riil negara tujuan ekspor (r_gdpc), jarak ekonomi (ecodist), populasi negara tujuan ekspor (pop), nilai tukar riil mata uang negara eksportir terhadap US\$ (r_exr), ad valorem tariff di negara tujuan ekspor (trf), dan jumlah Sanitary and Phytosanitary yang diberlakukan di negara importir (sps). Sedangkan variabel dependennya adalah volume ekspor komoditi hortikultura negara eksportir ke negara tujuan ekspor (eks).

\section{Harga Ekspor}

Harga ekspor berpengaruh signifikan dan nyata terhadap volume ekspor pada sebagian besar komoditi yang diestimasi. Nilai koefisien variabel harga ekspor yang bernilai positif sesuai dengan teori penawaran dan hipotesis pada penelitian ini. Nilai koefisien harga tertinggi adalah pada komoditi kentang di negara China yaitu sebesar 2,33. Hal ini berarti bahwa peningkatan harga sebesar satu\% akan meningkatkan 
volume ekspor komoditi kubis Amerika Serikat sebesar $2,33 \%$ ke dunia, cateris paribus. Berdasarkan nilai koefisien harga yang dihasilkan, terlihat bahwa hampir semua komoditi hortikultura baik di negara maju maupun negara berkembang tergolong ke dalam komoditi elastis, hanya komoditi kentang di negara Portugal dan nanas di Negara China yang tergolong ke dalam komoditi inelastis.

Tabel 3 Koefisien variabel penduga ekspor komoditas hortikultura di negara maju

\begin{tabular}{|c|c|c|c|c|c|c|}
\hline Variabel & Kentang & Kubis & Pisang & Nanas & $\begin{array}{l}\text { Jambu } \\
\text { Mangga } \\
\text { Manggis }\end{array}$ & Jahe \\
\hline \multicolumn{7}{|l|}{ Amerika Serikat } \\
\hline Ln(PROD_T_1) & 0,5388 & $-1,9092$ & $3,1895^{*}$ & $-1,2024$ & $-0,3662$ & 0,7915 \\
\hline Ln(P_EKS $)$ & 0,0313 & $2,0206 * *$ & $1,8469 * *$ & $1,9339 *$ & $1,7815^{*}$ & $1,5766^{*}$ \\
\hline Ln(R_GDPC) & $1,5674 * *$ & $2,4831 * *$ & $2,9146 * *$ & 1,7053 & 1,1506 & $-1,0764$ \\
\hline Ln(ECODIST) & $-0,5121$ & $-2,458 * *$ & $-3,3927 * *$ & $-1,3944$ & 0,1633 & 0,0288 \\
\hline Ln(R_EXR) & $-6,6483 * *$ & $25,821 * *$ & $-3,8190$ & $-0,8100$ & 1,6689 & $-0,2590$ \\
\hline $\operatorname{Ln}(\mathrm{POP})$ & $1,2003 * *$ & $3,3164 * *$ & $3,5672 * *$ & 2,1808 & 0,6668 & 0,1616 \\
\hline Ln(SPS) & $-0,0082$ & $-0,0636$ & 0,0907 & $-0,0379$ & $-0,0131$ & 0,2303 \\
\hline $\mathrm{TRF}$ & 0,0059 & $-0,0623^{*}$ & $-0,1632 * *$ & $-0,0360$ & 0,0496 & 0,0120 \\
\hline $\mathrm{C}$ & $-26,7638$ & $-19,6379$ & $-70,165 * *$ & $-15,8854$ & $-13,9499$ & 9,7381 \\
\hline \multicolumn{7}{|l|}{ Portugal } \\
\hline Ln(PROD_T_1) & 0,0135 & $3,8160 *$ & $3,9923 *$ & $-0,4752$ & - & - \\
\hline Ln(P_EKS $)$ & $0,8754 * *$ & $1,9082 * *$ & $1,7130 * *$ & $1,5509 * *$ & $1,4844 * *$ & $1,0163 * *$ \\
\hline Ln(R_GDPC) & 1,1812 & $5,8493 *$ & $39,7957 * *$ & $3,0945^{*}$ & 2,9008 & 0,2546 \\
\hline Ln(ECODIST) & $-0,7528$ & $-0,6575$ & $-31,230 * *$ & $-3,8467 * *$ & $2,3673 *$ & 0,7262 \\
\hline Ln(R_EXR) & 0,8455 & 0,2789 & 4,0090 & $-4,1402$ & 3,5783 & 2,4043 \\
\hline $\operatorname{Ln}(\mathrm{POP})$ & 1,0314 & $2,3619 *$ & $76,5316 * *$ & $4,8130 * *$ & $-3,0901$ & 7,3934 \\
\hline Ln(SPS) & $-0,0290$ & $1,5559 *$ & $-12,202 * *$ & 0,0579 & $-0,4137$ & - \\
\hline TRF & $-0,1315$ & $-3,121 * *$ & - & - & - & - \\
\hline $\mathrm{C}$ & 3,3467 & $213,970 *$ & $-1571,38^{*}$ & $-80,6249 *$ & 22,6934 & $-123,4616$ \\
\hline \multicolumn{7}{|l|}{ Australia } \\
\hline Ln(PROD_T_1) & $-5,5861$ & 1,9460 & $-0,8405$ & $-0,3436$ & 0,1747 & - \\
\hline Ln(P_EKS $)$ & $1,3795 * *$ & $1,2627 * *$ & $1,4391 * *$ & $1,3948 * *$ & $1,5678^{* *}$ & $1,2973 * *$ \\
\hline Ln(R_GDPC) & $\begin{array}{r}4,789 \\
3 * *\end{array}$ & $\begin{array}{r}0,17 \\
61\end{array}$ & $\begin{array}{r}5,60 \\
42\end{array}$ & 5,0850 & 1,0609 & $\begin{array}{r}1,381 \\
3\end{array}$ \\
\hline \multirow{2}{*}{ Ln(ECODIST) } & - & - & - & - & - & \\
\hline & $3,3666 * *$ & 0,1607 & $2,2916 *$ & 1,8786 & 0,2418 & 0,2255 \\
\hline \multirow{2}{*}{ Ln(R_EXR) } & 3,392 & 3,33 & 2,51 & 1,78 & 1,04 & 1,308 \\
\hline & $0 * *$ & $51 * *$ & 05 & $06 *$ & $61 * *$ & 2 \\
\hline \multirow{2}{*}{$\operatorname{Ln}(\mathrm{POP})$} & 3,510 & - & 4,27 & - & 0,51 & 0,244 \\
\hline & $6 * *$ & 0,0947 & $11 *$ & 3,5647 & 85 & 0 \\
\hline \multirow{2}{*}{$\operatorname{Ln}(\mathrm{SPS})$} & 0,163 & 0,12 & 0,80 & - & - & 0,003 \\
\hline & $8 * *$ & 88 & 67 & $0,3920 * *$ & $0,0727 * *$ & 9 \\
\hline \multirow{2}{*}{ TRF } & 0,167 & - & - & \multirow{2}{*}{ - } & - & 0,022 \\
\hline & $4 * *$ & 0,0779 & 0,0035 & & 0,0053 & 6 \\
\hline \multirow[t]{2}{*}{$\mathrm{C}$} & - & - & - & 27,5 & - & \\
\hline & 6,9565 & 3,9948 & 176,3716 & 833 & 10,5440 & 12,6523 \\
\hline
\end{tabular}

Keterangan: **) signifikan pada taraf nyata $1 \%$ dan *) signifikan pada taraf nyata5\% 


\section{GDP Perkapita Riil}

GDP riil perkapita merupakan proksi dari ukuran suatu negara, terutama dari sisi daya beli, terlihat bahwa sebagian besar nilai koefisien variabel ini menunjukkan nilai yang elastis (lebih besar dari 1). Namun, di negara produsen komoditi hortikultura utama dunia yaitu China, GDP riil perkapita tidak berpengaruh signifikan terhadap volume ekspor komoditi hortikultura.

Peningkatan pendapatan perkapita yang terjadi pada negara tujuan ekspor (negara pengimpor) akan meningkatkan permintaan ekspor beberapa produk hortikultura suatu negara. Penelitian yang dilakukan Anggita (2014) menunjukkan bahwa pendapatan atau GDP per kapita secara nyata mempengaruhi ekspor. Nilai koefisien GDP perkapita yang negatif sesuai dengan penelitian Ferro et al. (2014) yang menyatakan bahwa arus perdagangan akan meningkat seiring dengan besarnya GDP negara importir tidak selalu menjadi jaminan.

\section{Jarak Ekonomi}

Biaya ekspor (biaya transportasi) dalam penelitian ini diukur dengan nilai jarak ekonomi suatu negara. Jarak ekonomi merupakan salah satu syarat yang cukup penting pada gravity model dan besarnya jarak ekonomi akan mempengaruhi arus perdagangan ekspor secara negatif. Hasil estimasi yang diperoleh model menunjukkan bahwa variabel jarak ekonomi (ecodistance) memiliki hubungan yang negatif dan signifikan terhadap volume ekspor produk sebagian besar komoditi hortikultura di negara yang dianalisis, kecuali China sebagai negara produsen dan eksportir utama komoditi hortikultura dunia.

\section{Nilai Tukar Mata Uang}

Nilai tukar riil menyatakan tingkat dimana pelaku ekonomi dapat memperdagangkan barang-barang dari suatu Negara untuk barang-barang dari Negara lain sehingga terkadang disebut terms of trade (Mankiw, 2003). Sehubungan dengan transaksi perdagangan dunia menggunakan mata uang Dolar, maka pada penelitian ini nilai tukar yang digunakan dalam bentuk nilai mata uang negara eksportir per Dolar. Dengan demikian, apabila hasil estimasi menunjukkan tanda positif, maka diartikan bahwa kondisi tersebut adalah depresiasi. Begitu pula sebaliknya, tanda negatif menunjukkan terjadinya apresiasi.

Sebagaimana penelitian yang dilakukan oleh Ginting (2013) dimana apresiasi nilai rupiah akan dapat menurunkan ekspor komoditas Indonesia, maka terkait penelitian ini, dapat di tarik kesimpulan bahwa depresiasi nilai nilai mata uang negara eksportir terhadap dolar akan dapat meningkatkan volume ekspor. Sejalan dengan hal tersebut, Krugman (2012) menyebutkan bahwa perlemahan nilai mata uang rupiah terhadap mata uang asing (depresiasi nilai tukar) akan berdampak pada peningkatan volume ekspor.

Namun, pada nilai tukar mata uang yang memiliki hubungan yang negatif, artinya saat nilai tukar riil meningkat maka nilai tukar terapresiasi sehingga harga komoditi hortikultura domestik lebih mahal dibandingkan harga komoditi hortikultura luar negeri, maka permintaan ekspor komoditi hortikultura menurun. Hal ini bertentangan dengan hipotesis.

\section{Populasi}

Jumlah populasi dapat mempengaruhi ekspor dari dua sisi yaitu 
dari segi penawaran maupun permintaan. Pada sisi permintaan, pertumbuhan populasi akan dapat mendorong peningkatan konsumsi baik terhadap komoditi dalam negeri maupun luar negeri. Oleh karena itu, pertambahan penduduk akan mendorong peningkatan jumlah barang ekspor yang diminta. Perubahan populasi paling sensitif dihasilkan oleh komoditi pisang di negara Portugal yaitu dengan nilai elastisitas 76,53. Hal ini diduga karena komoditi pisang merupakan komoditi yang memiliki banyak kegunaan, selain sebagai produk akhir, pisang juga dapat digunakan sebagai bahan baku industri.

Tabel 4 Koefisien variabel penduga ekspor komoditas hortikultura di negara berkembang

\begin{tabular}{|c|c|c|c|c|c|c|}
\hline Variabel & Kentang & Kubis & Pisang & Nanas & $\begin{array}{c}\text { Jambu } \\
\text { Mangga } \\
\text { Manggis } \\
\end{array}$ & Jahe \\
\hline \multicolumn{7}{|l|}{ China } \\
\hline Ln(PROD_T_1) & $-1,7282$ & 0,4398 & $5,8944 *$ & $-0,7769$ & $6,1001 *$ & $-0,1589$ \\
\hline $\operatorname{Ln}\left(\mathrm{P} \_\right.$EKS $)$ & $2,3354 * *$ & $1,8541 * *$ & $1,3683^{* *}$ & $0,9266^{*}$ & $1,4507 * *$ & $1,7604 * *$ \\
\hline Ln(R_GDPC) & $-1,2693$ & 0,8420 & $-3,4165$ & $-0,0789$ & $-5,4282$ & 1,7247 \\
\hline $\operatorname{Ln}($ ECODIST) & 0,7361 & 1,2935 & 1,5052 & 0,0618 & $6,0742 * *$ & 1,0543 \\
\hline Ln(R_EXR) & $-1,7479 * *$ & $1,3913^{*}$ & $6,3887 * *$ & $-0,3876$ & $2,9034 * *$ & $-1,1479$ \\
\hline $\mathrm{Ln}(\mathrm{POP})$ & $-0,5098$ & $4,4072 *$ & 5,6474 & 0,2574 & $-10,4658$ & $-0,7546$ \\
\hline Ln(SPS) & $-0,0876^{*}$ & 0,0005 & 0,0530 & 0,0386 & $-0,0394$ & $-0,0680$ \\
\hline TRF & $-0,0457$ & 0,0279 & 0,0660 & 8,4885 & $-0,3258$ & $-0,0299$ \\
\hline $\mathrm{C}$ & $73,1382 * *$ & $-86,4245$ & $-175,4515$ & $-230,0460$ & 151,5989 & 14,7402 \\
\hline \multicolumn{7}{|l|}{ India } \\
\hline Ln(PROD_T_1) & $-2,2022 *$ & 4,4817 & 1,0683 & 0,0842 & $-0,1216$ & 0,5815 \\
\hline Ln(P_EKS $)$ & $2,0710^{* *}$ & $1,9056^{* *}$ & $1,0725 * *$ & $1,6909 * *$ & $1,8172 * *$ & $1,5700^{* *}$ \\
\hline Ln(R_GDPC) & $-1,5704 * *$ & 4,4321 & $-0,8364$ & 1,0407 & 1,1806 & $1,7229 * *$ \\
\hline Ln(ECODIST) & 0,0305 & $-4,0359 *$ & $-0,0427$ & $-1,0850$ & $-0,3722$ & $-1,3621 * *$ \\
\hline Ln(R_EXR) & 0,9225 & 0,0135 & $-1,2777$ & $-2,5290 *$ & $1,9899 *$ & $-2,3545^{*}$ \\
\hline $\mathrm{Ln}(\mathrm{POP})$ & $-0,1590$ & 2,9897 & 0,7624 & $1,7210^{*}$ & 0,7663 & $2,1285^{* *}$ \\
\hline $\operatorname{Ln}(\mathrm{SPS})$ & 0,0377 & 0,2590 & 0,0248 & 0,0530 & $-0,0300$ & $-0,0119$ \\
\hline TRF & $-0,1796$ & $-0,0950$ & 17,5972 & 0,1125 & $-0,0088$ & $-0,0185$ \\
\hline $\mathrm{C}$ & $85,6810 * *$ & $-123,7799$ & $-1859,284$ & $-26,1187$ & $-13,8508$ & $-32,6437^{*}$ \\
\hline \multicolumn{7}{|l|}{ Indonesia } \\
\hline Ln(PROD_T_1) & 1,7836 & 6,4599 & $-12,267 * *$ & 0,1179 & $-0,0405$ & $4,0931 * *$ \\
\hline $\mathrm{Ln}\left(\mathrm{P} \_\mathrm{EKS}\right)$ & $1,7453 * *$ & $1,7044 * *$ & $1,8199 * *$ & $1,5679 * *$ & $1,9113 * *$ & $1,8237 * *$ \\
\hline Ln(R_GDPC) & $16,1967 * *$ & $-5,3394$ & $20,5150 * *$ & 1,8356 & 0,7357 & 1,7118 \\
\hline Ln(ECODIST) & $-2,2968$ & 2,5935 & $-6,5339 *$ & $-0,8895$ & $-0,6635$ & $-1,9199$ \\
\hline Ln(R_EXR) & 1,9412 & $-1,0936$ & $4,3128^{*}$ & $9,9686^{* *}$ & $-1,7251 * *$ & $3,6424 * *$ \\
\hline $\mathrm{Ln}(\mathrm{POP})$ & $-15,4455$ & $-6,8068$ & $28,2887 * *$ & $-0,7694$ & 0,8807 & 2,3386 \\
\hline $\operatorname{Ln}(\mathrm{SPS})$ & $-4,6575 * *$ & 1,5039 & 3,2327 & 0,4770 & $-0,0986^{* *}$ & 0,0295 \\
\hline TRF & - & 0,0053 & $-0,2649$ & - & 0,0237 & 0,0436 \\
\hline $\mathrm{C}$ & 56,8576 & 90,0270 & $-459,8364$ & $-81,4013$ & 5,4336 & $-121,5647^{*}$ \\
\hline
\end{tabular}

Keterangan: **) signifikan pada taraf nyata $1 \%$ dan *) signifikan pada taraf nyata $5 \%$ 


\section{Tarif}

Tarif merupakan salah satu instrumen yang digunakan suatu negara dalam mengatur perdagangan lintas negara. Tarif ad valorem (ad valorem tariffs) adalah pajak yang dikenakan berdasarkan angka persentase tertentu dari nilai barang yang diimpor. Hasil estimasi menunjukkan bahwa variabel tarif berpengarh negatif yang signifikan dan nyata di negara-negara maju, yaitu pada komoditi kubis di negara Amerika Serikat dan Portugal serta komoditi pisang di negara Amerika Serikat dengan nilai koefisien berturut-turut sebesar -0,06; -3,12 dan -0,16 artinya, jika terjadi peningkatan tarif sebesar $1 \%$, maka volume ekspor kubis dari negara Amerika Serikat dan Portugal menurun $0,06 \%$ dan $3,12 \%$ serta volume ekspor pisang dari negara Amerika Serikat akan turun sebesar $0,16 \%$ ke dunia, cateris paribus.

\section{Sanitary and Phytosanitary (SPS)}

Variabel jumlah SPS negara tujuan ekspor pada model menujukkan pengaruh positif pada ekspor komoditi kentang di Portugal pada taraf $1 \%$ dengan nilai 0,16 . Koefisien positif pada dua variabel tersebut memperlihatkan bahwa ternyata kebijakan SPS tidak selalu memiliki dampak negatif pada perdagangan. Hasil koefisien SPS yang positif sejalan dengan penelitian yang dilakukan oleh Crivelli (2012).

KESIMPULAN DAN SARAN

\section{Kesimpulan}

Berdasarkan perhitungan RCA, negara-negara berkembang tersebut mendominasi perdagangan enam komoditas hortikultura di pasar dunia dengan nilai RCA lebih besar dari satu. Sedangkan dari hasil perhitungan EPD diperoleh tiga komoditas hortikultura yang memiliki pangsa pasar yang dinamis yaitu pisang dan nanas antar negara di pasar dunia, serta jahe dalam persaingan antar sesama negara berkembang.

Analisis data panel menunjukkan bahwa sebagian besar variabel bebas pada keenam komoditi hortikultura signifikan pada taraf nyata $5 \%$ dan memiliki koefisien yang sesuai dengan teori permintaan dan penawaran ekspor, meskipun ada sebagian nilai koefisien variabel bebas yang berkebalikan. Dengan demikian, faktor yang mempengaruhi aliran perdagangan (ekspor) di pasar dunia dipengaruhi oleh produksi tahun sebelumnya, harga ekspor, jumlah populasi negara importir, GDP perkapita riil negara importir, jarak ekonomi, dan nilai tukar riil.

Dampak liberalisasi perdagangan dicerminkan dengan kurang berpengaruhnya pemberlakuan tarif impor terhadap volume ekspor komoditi hortikultura dan nilai koefisiennya inelastis. Sementara itu untuk hambatan non tarif yaitu pemberlakuan SPS mempunyai pengaruh negatif terhadap hanya pada sebagian kecil ekspor komoditi hortikultura di pasar dunia.

\section{Saran}

Adanya
kebijakan Sengaruh $\begin{array}{r}\text { positif } \\ \text { pomoditi }\end{array}$ 
hortikultura membuktikan bahwa negara eksportir telah mampu memenuhi persayaratan dan standar yang diberlakukan oleh negara partner dagang. Pemerintah perlu melakukan pembenahan terkait aturan standar keamanan pangan khususnya untuk komoditi hortikultura Indonesia sehingga kualitas komoditi hortikultura yang dihasilkan meningkat dan pada akhirnya akan meningkatkan dayasaing serta nilai ekspornya sekaligus memperketat masuknya produk pertanian impor.

Penelitian selanjutnya diharapkan dapat melakukan penelitian terkait hambatan non tarif lainnya seperti technical barrier to trade (TBT), kuota dan fasilitasi perdagangan serta menggunakan metode pendekatan yang lainnya.

\section{DAFTAR PUSTAKA}

Anggita, TS. 2014. Analisis Perdagangan Kakao Indonesia di Pasar Internasional. Institut Pertanian Bogor. Bogor.

Balassa, B. 1989. Comparative Advantage, Trade Policy and Economic Development, Harvester Wheatsheaf, New York.

Bhattacharya KS, Bhattacharyay BN. 2007. Gains and Losses of IndiaChina Trade Cooperation - A Gravity Model Impact Analysis.CESIFO Working Paper No. 1970.

Crivelli P, Groschl J. 2012. The Impact of Sanitary and Phytosanitary Measures on Market Entry and Trade Flows. Geneva: Universite de Geneve.

[COMTRADE] Commodity Trade Statistics Database. 2015. Acces From World.

Dahar D. 2014. Analisis Dampak Kebijakan Non Tarif Terhadap
Kinerja Ekspor Hortikultura Indonesia ke Negara- negara ASEAN +3. Bogor: Institut Pertanian Bogor.

Estherhuizen, D. 2006. Measuring and Analyzing Competitiveness in the Agribusiness Sector: Methodological and Analytical Framework. University of Pretoria.

[FAO] Food and Agriculture Organization..]. Tersedia pada : http://faostat3.fao.org/download/Q /QC/E. [April 2015]

Ferro E, Otsuki T and Wilson J. 2015. The effect of product standards on agricultural exports. Food Policy 50 (2015) 68-79. Published by Elsevier Ltd.

Haryadi. 2008. Dampak Liberalisasi Perdagangan Pertanian Terhadap Perekonomian Negara Maju dan Berkembang. Institut Pertanian Bogor. Bogor.

Ginting, AM. 2013. Pengaruh Nilai Tukar terhadap Ekspor Indonesia. Buletin Ilmiah Litbang Perdagangan. 7 (1): 1-18. Jakarta: Kementerian Perdagangan.

Krugman PR, Obstfeld M, Melitz. 2012. International Economics, Theoryand Policy, Ninth Edition. NJ (US) : Addison-Wesley Publising Company.

Mankiw, N.G.2003. Teori Makroekonomi edisi kelima. Jakarta: Erlangga.

Mergenthaler, $\mathrm{M}$, Weinberger, $\mathrm{K}$ \& Qaim, K. 2009. The Food System Transformation in Developing Countries: A Disaggregate Demand Analysis for Fruits and Vegetables in Vietnam. Food Policy 34(5): 426-36.

Miet M, Johan S. 2014. Agricultural Trade And Development: A Value Chain Perspective. WTO Working Paper ERSD-2015-04. 
Saptana A. Agustian, H. Mayrowani, dan Sunarsih. 2006. Analisis Kelembagaan Kemitraan Rantai Pasok Komoditas Hortikultura. Pusat Analisis Sosial Ekonomi dan Kebijakan Pertanian. Badan Penelitian dan Pengembangan Pertanian. Departemen Pertanian.

[WDI] World Development Indicators. [Internet]. [Diunduh Januari 2015]. Tersedia pada: http://data.worldbank.org/datacatalog/world-developmentindicators.
Wei G, Huang J dan Yang J. 2012a. The Impact of Food Safety Standard on China's Tea Export. China Economic Review 23 (2012) 253264.

.2012b. Honey Safety Standard and Its Impact on China's Honey Export. Journal of Integrative Agriculture : 11(4) : 684-693.

World Bank. 2008. World Development Report 2008: Agriculture for Development. World Bank. Washington D. 